\title{
Electrochemical and Electrocatalytic Studies of Toluidine Blue Immobilized on a Silica Gel Surface Coated with Niobium Oxide
}

\author{
Antonio S. Santos, Arnaldo C. Pereira and Lauro T. Kubota* \\ Instituto de Química,Universidade Estadual de Campinas, CP 6154, 13083-970 Campinas - SP, Brazil
}

\begin{abstract}
O comportamento eletroquímico do azul de toluidina (AT) adsorvido sobre a superfície da sílica modificada com óxido de nióbio (SN) foi investigado, utilizando-se eletrodo de pasta de carbono modificada. A imobilização do AT sobre a SN proporcionou alta estabilidade ao eletrodo, por evitar a lixiviação do mediador da superfície do eletrodo. O potencial formal $\left(\mathrm{E}^{0^{\circ}}\right)$ do $\mathrm{AT}$ adsorvido foi -113 $\mathrm{mV}$ vs. ECS, indicando um deslocamento de aproximadamente $100 \mathrm{mV}$ para valores mais positivos de potenciais, comparado ao AT dissolvido em solução aquosa ou adsorvido em pasta de carbono. Em solução com pH no intervalo entre 5 e 8 não foi observada nenhuma diferença na estabilidade nem no potencial formal do sistema. A atividade eletrocatalítica, em soluções com $\mathrm{pH}$ neste intervalo, permaneceu praticamente constante, apresentando uma sensibilidade de $1,210^{-4} \mathrm{~A} \mathrm{~L} \mathrm{~mol}^{-1} \mathrm{~cm}^{-2} \mathrm{e} \mathrm{um}$ $\mathrm{K}_{\text {Mapp }}$ de 4,9 $10^{-5} \mathrm{~mol} \mathrm{~L}^{-1}$. Em soluções a pH 7,0 foi observada uma resposta linear para concentração de NADH no intervalo entre 2,0 $10^{-4}$ e $4,010^{-3} \mathrm{~mol} \mathrm{~L}^{-1}$ aplicando um potencial de $-50 \mathrm{mV} v \mathrm{~s}$. ECS. O sensor apresentou limite de detecção de $3,410^{-5} \mathrm{~mol} \mathrm{~L}^{-1}$, uma precisão de $1,0 \%$, expresso em desvio padrão relativo para 10 replicatas e tempo de resposta de aproximadamente $2 \mathrm{~s}$.
\end{abstract}

The electrochemical behavior of toluidine blue (TB) adsorbed on a silica surface modified with niobium oxide (SN) was investigated using a modified carbon paste electrode. The presence of SN gave the electrode high stability, avoiding the leaching out of the mediator from the electrode surface. The formal potential $\left(\mathrm{E}^{0^{*}}\right)$ of the adsorbed TB was $-113 \mathrm{mV} v s$. SCE, indicating a shift of almost 100 $\mathrm{mV}$ towards more positive potential values, compared to TB dissolved in aqueous solution or adsorbed on carbon paste. The stability and formal potential remained constant upon changing the solution $\mathrm{pH}$ in the range 5 to 8 . In these solution $\mathrm{pH}$ values the electrocatalytic activity remained almost constant with a sensitivity of $1.210^{-4} \mathrm{~A} \mathrm{~L} \mathrm{~mol}^{-1} \mathrm{~cm}^{-2}$ and a $\mathrm{K}_{\text {Mapp }}$ of $4.910^{-5} \mathrm{~mol} \mathrm{~L}^{-1}$. A linear response range for NADH concentration between $2.010^{-4}$ and $4.010^{-3} \mathrm{~mol} \mathrm{~L}^{-1}$ at $\mathrm{pH} 7.0$, with a detection limit of $3.410^{-5} \mathrm{~mol} \mathrm{~L}^{-1}$ was observed for the sensor. A response time of $2 \mathrm{~s}$ and a precision of $1.0 \%$, expressed as relative standard deviation for 10 replicates, were observed for the sensor developed.

Keywords: toluidine blue, niobium oxide modified silica, modified electrode, NADH, amperometric detection

\section{Introduction}

The electron transfer reaction between $\mathrm{NAD}(\mathrm{P}) \mathrm{H}$ and electrodes, modified with flavins, PQQ (pyrroloquinolinequinone) and similar compounds, such as phenoxazine, phenothiazine and phenazine, has been widely exploited. ${ }^{1,2}$ Many studies with organic dyes, immobilized in a carbon paste electrode, as efficient electrocatalysts for $\mathrm{NAD}(\mathrm{P}) \mathrm{H}$ oxidation, have been carried out by Gorton and co-workers. ${ }^{3,4}$ An alternative procedure to immobilize mediators for NADH electrooxidation such as electropolymerization of the

*e-mail: kubota@iqm.unicamp.br organic dye with conducting polymers, has also been published..$^{5-6}$ The carbon paste electrodes are the most used, since their surfaces are easily renewed, present low background current and have a wide range of working potential. ${ }^{7}$ Nevertheless, the incorporation of the species in the carbon paste still needs to be improved, mainly from stability and reproducibility aspects. ${ }^{8}$

Based on this context, materials that allow the immobilization of mediators and biological molecules are of great potential for sensor and biosensor development. ${ }^{9}$ Several works using zeolites, clays, zirconium phosphate and modified silica as supports for immobilization have been published. ${ }^{10-12}$ Modified silica present some important characteristics, such as: high surface area, rigidity, porosity 
and chemical stability, ${ }^{13}$ making them promising matrices. Although a great number of modified silicas are described in the literature,${ }^{14-15}$ only a small number have been devoted to electron mediator immobilization, with the objective of developing electrochemical sensors.

There are several kinds of silanol and siloxane groups on the silica surface. The silanol groups are considered to be strong adsorption sites. ${ }^{16}$ Silanols are weakly acid groups ( $\mathrm{pK}_{\mathrm{a}}$ around 7 ) which can be deprotonated by ammonia or organic amines. ${ }^{17}$ It has been shown that this ionization enhances the fixation of metal cations on silica surfaces. ${ }^{18-20}$ Silica based materials have attracted considerable attention, due to the advantages which couple the intrinsic properties of the inorganic matrix to the particular reactivity of the modifiers.

From the electrochemical point of view, such materials are attractive modifiers, typically for carbon paste electrodes, because they allow bringing to the electrode/ solution interface a large variety of covalently bonded organic functionalities, therefore preventing their leaching from the electrode into the solution. ${ }^{\text {? }}$

The use of chemically modified silica at an electrodesolution interface has attracted much attention, by exploiting the versatility of silica gel in immobilizing components such as oxides or electroative species. Silica gel has been modified with metal oxides, especially $\mathrm{Ti}$ (IV), $\mathrm{Zr}(\mathrm{IV}), \mathrm{V}(\mathrm{V})$ and $\mathrm{Nb}(\mathrm{V})$, resulting in a support materials for mediators immobilization. ${ }^{21}$

For biosensors based on dehydrogenases enzymes, that correspond to the largest group of known redox enzymes, use of an electron acceptor $\left(\mathrm{NAD}^{+} / \mathrm{NADP}^{+}\right)$or an electron donor (NADH/NADPH) is necessary. However, the necessity of a high overpotential to promote the direct electrooxidation of $\mathrm{NAD}(\mathrm{P}) \mathrm{H}$ limits its application for practical purposes, due to parallel reactions which lead to interference in the system and poison the electrode surface. This problem may be solved by immobilization of electron mediators on the electrode surface. ${ }^{22}$

The immobilization of the electron mediators in carbon electrodes for NADH eletrooxidation has been extensively investigated in the last two decades. ${ }^{22-24}$ The electron-proton transfer in this kind of reaction is a subject of great interest in many fields of science, ${ }^{25,26}$ mainly in biological systems. ${ }^{27,28}$ Many works describing electrodes modified with mediators and dehydrogenases have been published. ${ }^{29,30}$ In general, a lot of electrochemical investigations on electron transfer between NADH and the electron mediators have been carried out, in an attempt to improve the electron transfer rate. ${ }^{31,32}$

In this way, these new electrodes have shown an improvement in the catalytic reaction of $\mathrm{NADH},{ }^{33-35}$ as a result of the immobilization process on the electrode..$^{36}$ The electrodic material may affect the formal potential of the electroactive species and its stability depends on the immobilization procedure. ${ }^{37}$ Therefore, investigation of the electrocatalytic oxidation of NADH by modified silica based electrodes with mediators similar to the flavins is of great importance.

An investigation of the use of niobium oxide modified silica with to adsorb toluidine blue, in a strongly form, to apply to an electrochemical study of NAD $(\mathrm{P}) \mathrm{H}$ electrooxidation is described.

\section{Experimental}

Reagents

Silica gel (Fluka) with an average pore diameter of $6 \mathrm{~nm}$; specific surface area of $520 \mathrm{~m}^{2} \mathrm{~g}^{-1}$, and particle size of 0.05-0.2 mm, previously activated at $150{ }^{\circ} \mathrm{C}$ for $2 \mathrm{~h}$, was used. Graphite powder (99.9\%, BDH), mineral oil (Aldrich), niobium pentachloride (Aldrich), nicotinamide adenine dinucleotide, reduced form, (NADH, Sigma) and toluidine blue (Sigma) were used with no previous treatment. The other reagents used were of analytical grade.

\section{Preparation of niobium oxide modified silica (SN)}

For silica gel modification, $22 \mathrm{~g}$ of $\mathrm{NbCl}_{5}$ (Fluka) (0.081 $\mathrm{mol}$ ) was dissolved in $40 \mathrm{~mL}$ of ethanol (Merck). After that $300 \mathrm{~mL}$ of carbon tetrachloride was added to this solution. In the following step, $50 \mathrm{~g}$ of silica was added and the resulting mixture was refluxed for $20 \mathrm{~h}$ under constant shaking. The resulting material was filtered, washed with carbon tetrachloride and ethanol and dried for $4 \mathrm{~h}$ at a temperature of $140{ }^{\circ} \mathrm{C}$. The dried material was immersed in doubly distilled water for several hours. The final product was dried at $100{ }^{\circ} \mathrm{C}$ for $4 \mathrm{~h}$. It is denominated SN.

\section{Toluidine blue adsorption on SN}

Initially, $500 \mathrm{mg}$ of $\mathrm{SN}$ was added to $20 \mathrm{~mL}$ of a $0.1 \%$ $(w / v)$ toluidine blue solution. This mixture was shaken for $2 \mathrm{~h}$, and then filtered. The solid was washed with distilled water and dried at room temperature for two days. The final product of this reaction was denominated as SNTB.

\section{Material characterization}

The quantity of niobium grafted onto the silica gel was determined by X-ray fluorescence, using a Tracor model 5000 spectrometer from Spectrace. 
The specific surface area of the silica was determined by the BET method, using a Micromeritics FlowSorb II model 2300 .

The quantification of toluidine blue adsorbed on the silica surface was carried out by elemental analysis, using a Perkin Elmer-2400 Elemental Analyzer.

\section{Preparation of the modified carbon paste electrode}

For the electrode preparation, $20 \mathrm{mg}$ of SNTB and 20 $\mathrm{mg}$ of graphite powder were mixed and homogenized. After that, a small amount of mineral oil was added and mixed until a homogeneous paste was obtained. This paste was placed into the cavity of a glass tube with $5 \mathrm{~mm}$ internal diameter, obtaining the modified carbon paste electrode, CPE/SNTB.

\section{Electrochemical measurements}

The electrochemical study of SNTB and electrocatalytic oxidation of NADH were carried out with a PGSTAT10 potentiostat from Autolab, using a conventional three electrode electrochemical cell, with a saturated calomel electrode, SCE (Corning, St. Louis, USA) as the reference, a platinum wire as auxiliary and the modified carbon paste electrode as working electrode.

\section{Results and Discussion}

Although $\mathrm{NbCl}_{5}$ is insoluble in carbon tetrachloride, prior addition to ethanol produces a partially substituted $\mathrm{NbCl}_{5-\mathrm{n}}\left(\mathrm{OC}_{2} \mathrm{H}_{5}\right)_{\mathrm{n}}$ species, which is soluble in the reaction medium. The equations that describe the reactions of the silica modification can be represented as:

$$
\begin{aligned}
\mathrm{n} \equiv & \mathrm{SiOH}+\mathrm{Nb}\left(\mathrm{OC}_{2} \mathrm{H}_{5}\right)_{5} \rightarrow(\equiv \mathrm{SiO})_{\mathrm{n}} \mathrm{Nb}\left(\mathrm{OC}_{2} \mathrm{H}_{5}\right)_{5-\mathrm{n}} \\
& +\mathrm{nC}_{2} \mathrm{H}_{5} \mathrm{OH} \\
(\equiv & \mathrm{SiO})_{\mathrm{n}} \mathrm{Nb}\left(\mathrm{OC}_{2} \mathrm{H}_{5}\right)_{5-\mathrm{n}}+(5-\mathrm{n}) \mathrm{H}_{2} \mathrm{O} \rightarrow(\equiv \mathrm{SiO})_{\mathrm{n}} \mathrm{Nb}(\mathrm{OH})_{5-\mathrm{n}} \\
& +(5-\mathrm{n}) \mathrm{C}_{2} \mathrm{H}_{5} \mathrm{OH}
\end{aligned}
$$

The amount of niobium oxide coated on the silica gel surface, determined by X-ray fluorescence spectrometry, was $1.4 \mathrm{mmol} \mathrm{g}^{-1}$. This amount is higher when compared with the results described in the literature, ${ }^{21}$ for other metal oxides like titanium and zirconium.

The hydroxyl groups of niobium oxide are known to be acidic, which should be responsible for adsorption of toluidine blue.

The specific surface areas for the pure and niobium oxide modified silica gel were obtained by the multipoint
BET method. After the modification, the silica gel surface showed a small decrease, $496 \pm 7 \mathrm{~m}^{2} \mathrm{~g}^{-1}$, compared to the initial area, $520 \pm 8 \mathrm{~m}^{2} \mathrm{~g}^{-1}$. This decrease is related to the blocking of smaller pores of silica during the modification process, as well as the coalescence of some pores.

The amount of toluidine blue adsorbed on the modified silica surface, obtained by elemental analysis, was $59 \mu \mathrm{mol} \mathrm{g}^{-1}$, similar to that observed in the literature ${ }^{38}$ for other phenothiazines.

\section{Electrochemical properties of CPE/SNTB}

Figure 1(A) shows the cyclic voltammogram of a CPE/ $\mathrm{SN}$ electrode, and no redox peak was observed, while Figure 1(B) shows the cyclic voltammogram of a CPE/SNTB sensor, which presents a redox couple of the mediator with a formal potential $\left(\mathrm{E}^{0^{\prime}}\right)$ of $-113 \mathrm{mV}$ vs SCE. $\mathrm{E}^{0^{\prime}}=(\mathrm{Epa}+$ $\mathrm{Epc}) / 2$ where $\mathrm{E}_{\mathrm{pa}}$ is the anodic peak potential and $\mathrm{E}_{\mathrm{pc}}$ is the cathodic peak potential. ${ }^{39}$ Comparing this formal potential with those obtained for toluidine blue in aqueous solution $\left(-210 \mathrm{mV} v s \mathrm{SCE}^{40}\right)$, a shift of $97 \mathrm{mV}$ towards more positive values is observed. Comparing the formal potential of $-200 \mathrm{mV}$ vs SCE obtained for toluidine blue adsorbed on carbon paste, ${ }^{41}$ a shift of $87 \mathrm{mV}$ towards more positive values is observed. This behavior suggests a stronger interaction between the reduced form of TB and the matrix than with the oxidized form. A possible explanation for this behavior can be assigned to either the acidity of the material or an interaction of the nitrogen atom of the mediator with SN. ${ }^{42}$ Similar behavior was verified for phenoxazine, phenothiazine and phenazine adsorbed in zirconium phosphate ${ }^{43}$ and titanium phosphate. ${ }^{44}$

The electron transfer of TB on the electrode is an important aspect to be considered in the system, as can be

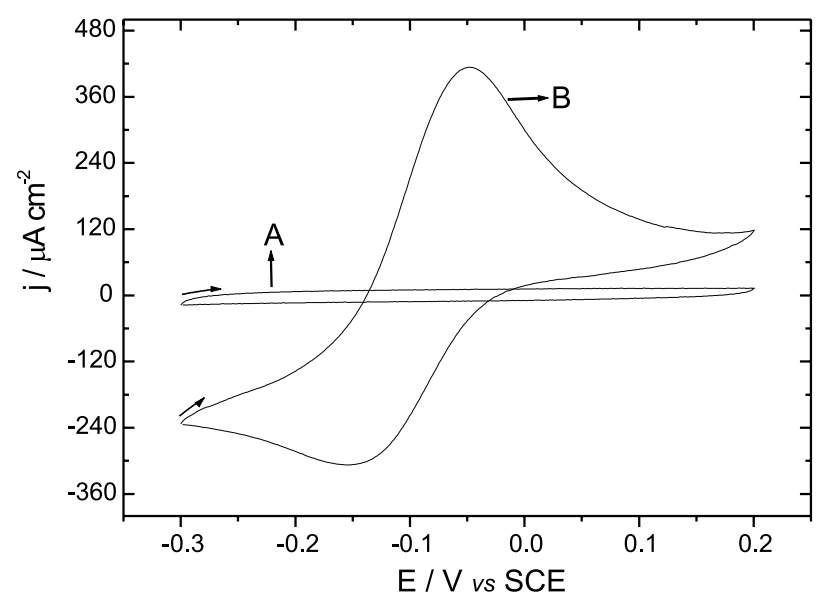

Figure 1. Cyclic voltammograms obtained with $\mathrm{CPE} / \mathrm{SN}$ (A) and CPE/SNTB (B) sensors, in a $0.5 \mathrm{~mol} \mathrm{~L}^{-1} \mathrm{KCl}$ solution, $\mathrm{pH} 7.0$, for a scan rate of $10 \mathrm{mVs}^{-1}$. 
Table 1. Peak separation, $\Delta \mathrm{E}_{\mathrm{p}}$, and formal potential, $\mathrm{E}^{0^{\prime}}$, obtained for the CPE/SNTB sensor in different supporting electrolytes at concentrations of $0.5 \mathrm{~mol} \mathrm{~L}^{-1}, \mathrm{pH} 7.0$, for a scan rate of $10 \mathrm{mV} \mathrm{s}^{-1}$

\begin{tabular}{lrrrrrrrr}
\hline & $\mathrm{LiCl}$ & $\mathrm{KCl}$ & $\mathrm{BaCl}_{2}$ & $\mathrm{CaCl}_{2}$ & $\mathrm{NaCl}$ & $\mathrm{NaNO}_{3}$ & $\mathrm{Na}_{2} \mathrm{SO}_{4}$ & $\mathrm{NaClO}_{4}$ \\
\hline$\Delta \mathrm{Ep}(\mathrm{mV})$ & 120 & 120 & 130 & 130 & 125 & 130 & 130 & 135 \\
$\mathrm{E}^{0^{\prime}}(\mathrm{mV})$ & -113 & -113 & -115 & -115 & -114 & -116 & -116 & -130 \\
\hline
\end{tabular}

observed by the peak separation, even at a low scan rate. For a scan rate of $10 \mathrm{mV} \mathrm{s}^{-1}$, a peak separation, $\Delta \mathrm{E}_{\mathrm{p}}$, of 120 $\mathrm{mV}$ was verified, indicating that the electron transfer is not fully reversible. This behavior can be assigned to the ohmic drop of the carbon paste prepared with SNTB. Probably the electron transfer is due to electron hopping.

Observing the data of Table 1, no influence of the nature of the supporting electrolyte is verified, except for perchlorate, which presented a midpoint potential of $-130 \mathrm{mV}$ vs SCE. This behavior can be attributed to the great affinity of perchlorate ion for the quaternary nitrogen in the amine compound..$^{45}$ The competition between $\mathrm{SN}^{46,47}$ and the perchlorate for interaction with the nitrogen of the organic dye may minimize the effect of the matrix, causing a smaller shift in the formal potential.

The peak separation, $\Delta \mathrm{E}_{\mathrm{p}}\left(\Delta \mathrm{Ep}=\mathrm{E}_{\mathrm{pa}}-\mathrm{E}_{\mathrm{pc}}\right)$ for all supporting electrolytes tested was almost the same, between 120 and $135 \mathrm{mV}$, Table 1 . Probably the reduced and oxidized forms of the mediator interact in the same way with different supporting electrolytes.

Experiments carried out in different concentrations of the supporting electrolyte showed that, for values higher than $0.1 \mathrm{~mol} \mathrm{~L}^{-1}$, no significant influence was observed in the peak separation or current level. This behavior suggests the good mobility of the ions maintaining the electroneutrality of the electrode surface. However, the redox process is not fully reversible. Resistance of the carbon paste could be responsible for this behavior.

A great stability of TB immobilized on $\mathrm{SN}$ was observed, cycling the CPE/SNTB electrode for many times with a scan rate of $10 \mathrm{mV} \mathrm{s}^{-1}$. The current level remained almost constant (Table 2), indicating that the mediator does not leach out from the electrode surface, even after several hours.

Table 2. Peak current observed for the CPE/SNTB sensor after successive cyclic voltammograms, in $0.5 \mathrm{~mol} \mathrm{~L}^{-1} \mathrm{KCl}$ solution, $\mathrm{pH} 7.0$, for a scan rate of $10 \mathrm{mVs}^{-1}$ over the potential range between -0.3 and $0.2 \mathrm{~V}$

\begin{tabular}{lccccccc}
\hline Cycle & 10 & 20 & 30 & 40 & 50 & 80 & 100 \\
\hline $\mathrm{j} /\left(\mu \mathrm{A} \mathrm{cm}^{-2}\right)$ & 358 & 358 & 359 & 358 & 359 & 360 & 360 \\
\hline
\end{tabular}

Another important aspect of this sensor that should be emphasized is the linear correlation between the peak current and the square root of the scan rate (Figure 2) over the range of $5-100 \mathrm{mV} \mathrm{s}^{-1}$. This behavior is similar to that observed for the diffusion controlled process. ${ }^{48}$ Since no loss of the mediator was observed even after long period, indicating that $\mathrm{TB}$ is strongly adsorbed on $\mathrm{SN}$, the diffusion of the ions of the supporting electrolytes could be the responsible for electroneutrality maintenance on the electrode surface. This behavior is often observed when inorganic materials, such as silica or metallic phosphate, is mixed in carbon paste. ${ }^{49}$ However, no influence of diffusion of electrolyte was observed, suggesting the ohmic drop in the electrode is due to the electron hopping mechanism.

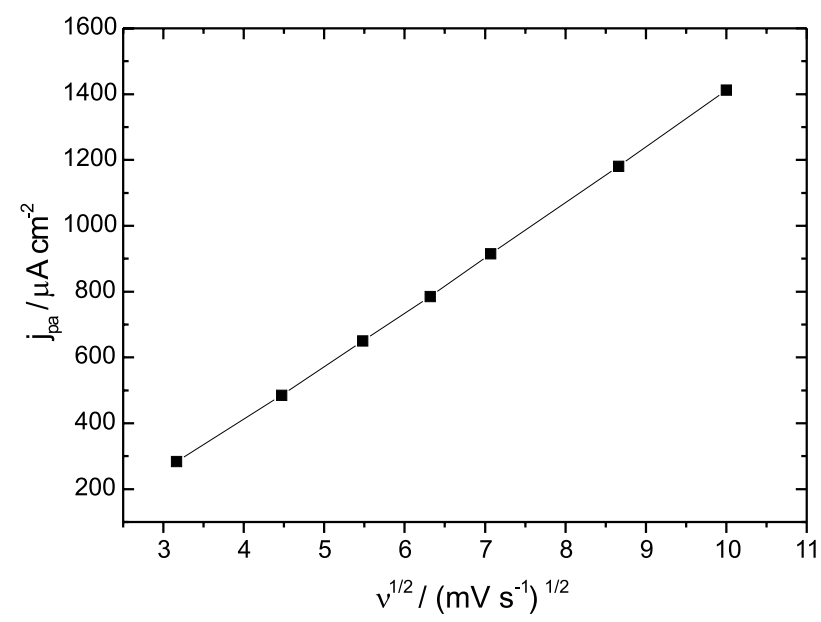

Figure 2. Dependence of the peak current as a function of the square root of the scan rate obtained for CPE/SNTB sensor in $0.5 \mathrm{~mol} \mathrm{~L}^{-1} \mathrm{KCl}$ solution at $\mathrm{pH}$ 7.0.

The formal potential of TB adsorbed on $\mathrm{SN}$ was independent of the solution $\mathrm{pH}$ from 5.0 to 8.0 (Table 3). This behavior in the formal potential has been attributed to the matrix effect, minimizing the influence of solution $\mathrm{pH}$ on the adsorbed dye. However, for $\mathrm{pH}$ lower than 5.0, a shift of $\mathrm{E}^{0}$ to more positive potentials is observed, suggesting that the protection effect of the matrix is ineffective for higher concentrations of $\mathrm{H}^{+}$. This invariance 
of $\mathrm{E}^{0^{\prime}}$ between $\mathrm{pH} 5$ and 8 may be attractive for pratical aspects and mechanism studies of the reaction between NADH and TB adsorbed on SN. Minimizing the influence of $\left[\mathrm{H}^{+}\right]$on the redox process of SNTB, the NADH electrooxidation would be affected only by the formal potential of NADH. This aspect is very important to verify the effect of the thermodynamic driving force on the reaction between NADH and TB.

Table 3. Formal potential, $\mathrm{E}^{0}$, and peak separation, $\Delta \mathrm{Ep}$, as a function of the solution $\mathrm{pH}$, obtained for the CPE/SNTB sensor at a scan rate of $10 \mathrm{mV} \mathrm{s}^{-1}$

\begin{tabular}{ccc}
\hline $\mathrm{pH}$ & $\Delta \mathrm{E}_{\mathrm{p}} / \mathrm{mV}$ & $\mathrm{E}^{0^{\prime}} / \mathrm{mV}$ \\
\hline 2.0 & 90 & -80 \\
3.0 & 90 & -85 \\
4.0 & 100 & -100 \\
5.0 & 120 & -110 \\
6.0 & 120 & -110 \\
7.0 & 120 & -113 \\
8.0 & 120 & -113 \\
\hline
\end{tabular}

Study of the NADH electro-oxidation

Electrocatalytic NADH oxidation has been possible through the use of electron mediators at about $-300 \mathrm{mV}$ vs $\mathrm{SCE}^{44}$ at $\mathrm{pH} 7.0$ in solution or when immobilized in conventional electrodes. However, there is a great interest in finding other mediators or procedures to immobilize them on electrode surfaces, which can result in an increase in the reaction rate. A linear relationship between $\mathrm{k}_{\mathrm{obs}}$ and the formal potential of the immobilized mediator has been observed. ${ }^{44}$ An increase in $\mathrm{k}_{\mathrm{obs}}$, as a consequence of the formal potential shift to more positive values at constant $\mathrm{pH}$, is expected. ${ }^{50}$ The invariance of the formal potential, around $-110 \mathrm{mV}$ vs SCE, from $\mathrm{pH} 5$ to 8, makes this sensor an interesting instrument for the study of the reaction mechanism between NADH and TB ${ }^{51}$ Previous studies with adsorbed mediators showed a mechanism that involves 2 electron-1-proton, indicating that the $\mathrm{k}_{\mathrm{obs}}$ is very dependent on the solution $\mathrm{pH}$. This dependence is not fully explained, but it could be a result of the shift of the formal potential of $\mathrm{NAD}^{+} / \mathrm{NADH}$ and immobilized mediator, affecting the thermodynamic potential of the reaction/catalysis with an inherent dependence on solution $\mathrm{pH} .{ }^{43}$ Therefore, a behavior study of the electrocatalytic oxidation of NADH by mediators capable of improving the rate of electron transfer in this reaction, using the resources of on electrochemical technique, becomes of great importance.

The CPE/SNTB sensor promoted the electrocatalytic oxidation of NADH, as is clearly observed from cyclic voltammograms in the absence (Figure $3 \mathrm{~A}$ ) and in the presence (Figure 3B) of $1.010^{-3} \mathrm{~mol} \mathrm{~L}^{-1} \mathrm{NADH}$. The applied potential dependence on the electrode response obtained for a $1.010^{-3} \mathrm{~mol} \mathrm{~L}^{-1} \mathrm{NADH}$ solution is shown in Figure 4. The electrooxidation of NADH begins at $-200 \mathrm{mV}$ vs SCE and reaches a maximum response at $-50 \mathrm{mV}$ vs SCE. The influence of the solution $\mathrm{pH}$ on the NADH electrooxidation is very important to obtain new information about the mechanism of this reaction. At solution $\mathrm{pH}$ from 5 to 8 the response remained constant (Table 4), in accordance with the invariance of the formal potential for the experiment carried out with the CPE/SNTB electrode.

The system presented the best response in a phosphate buffer solution, as can be observed in Table 5. A possible explanation for this behavior can be the formation of a

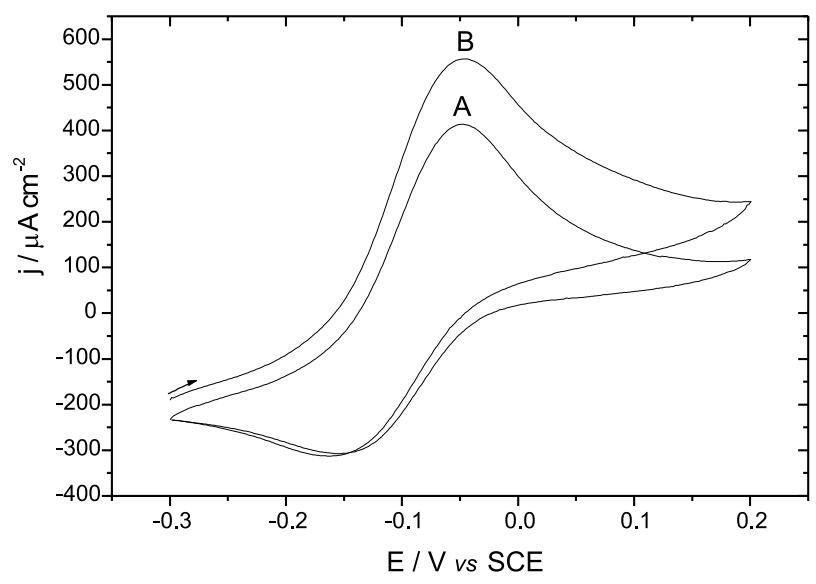

Figure 3. Cyclic voltammograms obtained with CPE/SNTB sensor, in the absence (A) and in the presence (B) of $1.010^{-3} \mathrm{~mol} \mathrm{~L}^{-1} \mathrm{NADH}$ in $0.5 \mathrm{~mol} \mathrm{~L}^{-1} \mathrm{KCl}$ solution at $\mathrm{pH} 7.0$, for a scan rate of $10 \mathrm{mV} \mathrm{s}^{-1}$.

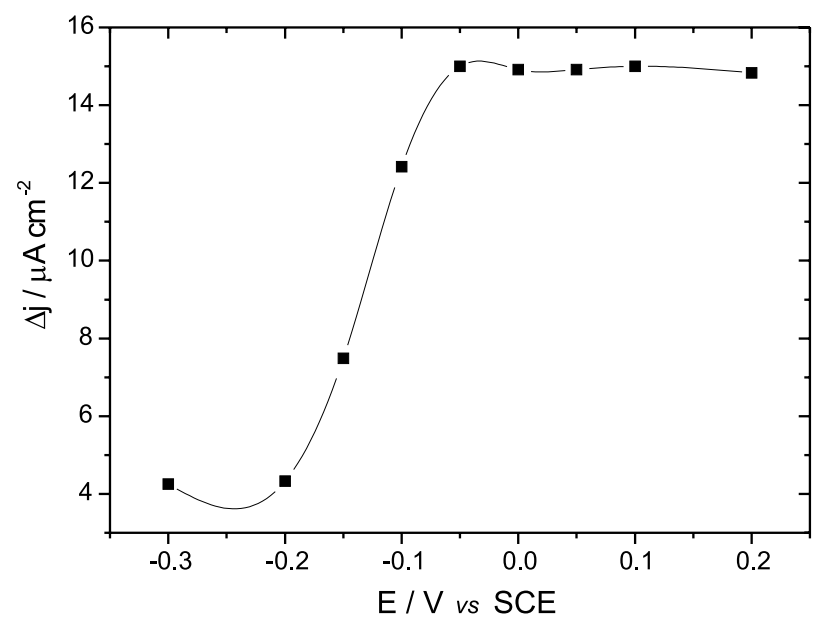

Figure 4. Dependence of the electrocatalytic current as a function of the applied potential, obtained for the CPE/SNTB sensor in the presence of $1.010^{-3} \mathrm{~mol} \mathrm{~L}^{-1} \mathrm{NADH}$ in a $0.5 \mathrm{~mol} \mathrm{~L}^{-1} \mathrm{KCl}$ solution, $\mathrm{pH}$ 7.0 . 
Table 4. Effect of the solution $\mathrm{pH}$ on NADH electrooxidation, using the CPE/SNTB sensor in the presence of $1.010^{-3} \mathrm{~mol} \mathrm{~L}^{-1} \mathrm{NADH}$ solution prepared in $0.5 \mathrm{~mol} \mathrm{\textrm {L } ^ { - 1 }} \mathrm{KCl}$ solution, with an applied potential of $-50 \mathrm{mV}$ vs SCE

\begin{tabular}{cc}
\hline $\mathrm{pH}$ & $\Delta \mathrm{j} / \mu \mathrm{A} \mathrm{cm}{ }^{-2}$ \\
\hline 5.0 & 14.2 \\
6.0 & 14.2 \\
6.5 & 14.1 \\
7.0 & 14.2 \\
7.5 & 14.1 \\
8.0 & 14.1 \\
\hline
\end{tabular}

Table 5. Catalytic current for NADH $\left(\begin{array}{llll}1.0 & 10^{-3} & \mathrm{~mol} \mathrm{~L} & -1\end{array}\right)$ electrooxidation in different buffer at $\mathrm{pH} 7.0$ with an applied potential of $-50 \mathrm{mV}$ vs. SCE, obtained for CPE/SNTB sensor

\begin{tabular}{cc}
\hline Buffer & $\Delta \mathrm{j} / \mu \mathrm{A} \mathrm{cm}$ \\
\hline Phosphate & 17.5 \\
Tris & 13.3 \\
Hepes & 9.2 \\
Pipes & 8.3 \\
\hline
\end{tabular}

compound between NADH and phosphate, such as an adduct with the NADH oxidation becoming easier. ${ }^{52}$

The catalytic current as a function of $\mathrm{NADH}$ concentration is presented in Figure 5 and clearly shows a good linear relationship in the concentration range between $2.010^{-4}$ to $4.010^{-3} \mathrm{~mol} \mathrm{~L}^{-1}$ with a sensitivity of $1.210^{-4} \mathrm{~A} \mathrm{~L}$ $\mathrm{mol}^{-1} \mathrm{~cm}^{-2}$. The linear equation is fitted by $\mathrm{j}=5.13( \pm 0.42)$ $10^{-6}+12.2( \pm 0.16) 10^{-3}[\mathrm{NADH}]$, with a correlation coefficient of 0.9992 for $n=9$, where $\mathrm{j}$ is the current density given in $\mu \mathrm{A} \mathrm{cm}^{-2}$ and NADH concentration is in $\mathrm{mmol} \mathrm{L}^{-1}$. The detection limit at the optimized conditions is $3.410^{-5} \mathrm{~mol} \mathrm{~L}^{-1}$, considered as three times the noise with a

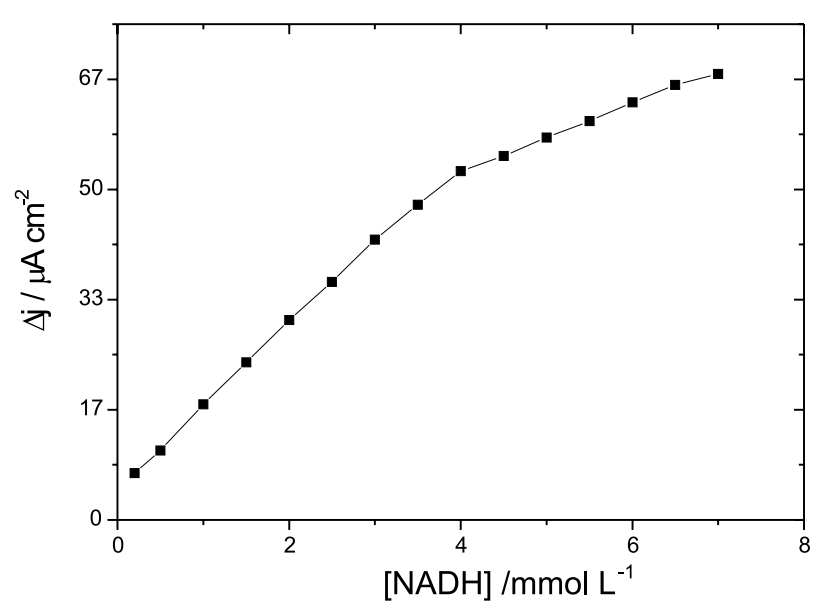

Figure 5. Analytical curve obtained with the CPE/SNTB sensor, applied potential of $-50 \mathrm{mV}$ vs SCE in $0.5 \mathrm{~mol} \mathrm{~L}^{-1}$ phosphate buffer solution at $\mathrm{pH} 7.0$. precision of $1.0 \%$, expressed as relative standard deviation for 10 replicates. The electrode response time was about 2 $\mathrm{s}$, which is defined as the time necessary for the catalytic current to reach the maximum response. Considering the saturation region of the analytical curve (concentration range from $4.010^{-3}$ up to $7.010^{-3} \mathrm{~mol} \mathrm{~L}^{-1}$ ), a double reciprocal graph was plotted and the apparent MichaelisMenten constant, $\mathrm{K}_{\text {Mapp }}$, was estimated as being $4.910^{-5}$ mol L ${ }^{-1}$. This value is quite low, when compared to other systems, such as meldola blue adsorbed on graphite ${ }^{37}$ and nile blue adsorbed on zirconium phosphate ${ }^{47}$. However, it is similar to meldola blue adsorbed on $\mathrm{SN},{ }^{46} 6.110^{-5} \mathrm{~mol}$ $\mathrm{L}^{-1}$. This low value of the apparent Michaelis-Menten constant suggests the great affinity of SNTB for NADH may be due to charge transfer complex formation. Since the formal potential of TB adsorbed on SN is constant from $\mathrm{pH} 5$ to 8 , an increase in the electro-oxidation due to the NADH redox couple shift of $30 \mathrm{mV}$ per $\mathrm{pH}$ unit towards more negative potentials would be expected, increasing the thermodynamic driving force. This behavior suggests that solution $\mathrm{pH}$ affects the charge transfer complex formation, minimizing the thermodynamic driving force effect. The catalytic current reaches a maximum in about $2 \mathrm{~s}$. This sensor also presented stability for accomplishment of more than 300 samples without significant change.

\section{Conclusions}

The use of the niobium oxide modified silica gel to immobilize TB presents great potential to develop new sensors for NADH as well as to investigate the behavior of NADH electro-oxidation. This sensor presented good stability as the current level remained almost constant even after a long period of use, confirming the strong adherence of the dye in the matrix. A high electrocatalytic activity for NADH oxidation was observed, which might be explained for the shift of $\mathrm{E}^{0^{\prime}}$ towards a more positive value. This shift of $\mathrm{E}^{0^{\prime}}$ for $\mathrm{TB}$ adsorbed on $\mathrm{SN}$, in combination with the invariance of the formal potential from solution $\mathrm{pH}$ of 5 to 8 , made this sensor very attractive to study the mechanism of the reaction between NADH and adsorbed TB. In the present study good evidence that the mechanism is governed by a thermodynamic driving force and charge transfer complex formation were verified. This will contribute to shedding new insights into NADH oxidation by the electron mediator modified electrode.

\section{Acknowledgments}

The authors acknowledge Prof. Carol Collins for English revision of the manuscript and FAPESP for financial support. 


\section{References}

1. Nagy, G.; Kapui, I.; Gorton, L.; Anal. Chim. Acta 1995, 305, 65 .

2. Katz, E.; Lotzbeyer, T.; Schlereth, D. D.; Schuhmann, W.; Schmidt, H.L.; J. Electroanal. Chem. 1994, 373, 189.

3. Dominguez, E.; Lan, H. L.; Okamoto, Y.; Hale, P. D.; Skotheim, T. A.; Gorton, L.; Hahnhagerdal, B.; Biosens. Bioelectron. 1993, 8, 229.

4. Ni, F.; Feng, H.; Gorton, L.; Cotton, T. M.; Langmuir 1990, 6, 66.

5. Cosnier, S.; Fontecave, M.; Limosin, D.; Nivière, V.; Anal. Chem 1997, 69, 3095.

6. Pariente, F.; Tobalina, F.; Darder, M.; Lorenzo, E.; Abruña, H. D.; Anal. Chem. 1996, 68, 3135.

7. Kalcher, K.; Kauffmann, J. M.; Wang, J.; Svancara, I.; Vytras, K.; Neuhold, C.; Yang, Z.; Electroanalysis 1995, 7, 5.

8. Mullor, S. G.; Sánchez-Cabezudo, M.; Ordieres, A. J. M.; Ruiz, B. L.; Talanta 1996, 43, 779.

9. Gorton, L.; Karan, H. I.; Hale, P. D.; Inagaki, T.; Okamoto, Y.; Skothein, T. A.; Anal. Chim. Acta 1990, 228, 23.

10. Palecek, E.; Electroanalysis 1996, 8, 7.

11. Kubota, L. T.; Gushikem, Y.; Perez, J.; Tanaka, A. A.; Langmuir 1995, 11, 1009.

12. Rolison, D. R.; Chem. Rev. 1990, 90, 867.

13. Katakis, I.; Domínguez, E.; Mikrochim. Acta 1997, 126, 11.

14. Vansant, E. F.; Van der Voort, P.; Vrancken, K. C.; "Characterization and Chemical Modification of the Silica Surface" Elsevier, Amsterdam, 1995.

15. Citta, L. A.; Hurtubise, R. J.; Talanta 1992, 39, 1065.

16. Hair, M. L.; Hertl, W.; J. Phys. Chem. 1969, 73, 4269.

17. Titova, T. I.; Kosheleva, L. S.; Colloids Surf. 1992, 63, 97.

18. Iler, R.K.; The Chemistry of Silica, Wiley, New York, 1979.

19. Robertson, A. P.; Leckie, J. O.; J. Colloid Interface Sci. 1997, 188, 444.

20. Walcarius, A.; Bessière, J.; Anal. Chim. Acta 1998, 361, 273.

21. Gushikem, Y.; Rosatto, S. S.; J. Braz. Chem. Soc. 2001, 12, 695.

22. Gorton, L.; Domínguez, E.; Encyclopedia of Electrochemistry, (Eds. Bard, A.J., Stratmann, M.), Vol. 9, Bioelectrochemistry, Wiley-VCH, 2002. In press.

23. Lobo, M. J.; Miranda, A. J.; Tunon, P.; Electroanalysis 1997, 9, 191

24. Sled, V. D.; Rudnitzky, N. I.; Hatefi, Y.; Ohnishi, T.; Biochemistry 1994, 33, 10069.

25. Palfey, B. A.; Ballou, D. P.; Massey, V.; Biochemistry 1997, 36, 15713.

26. Morre, D. J.; Caldwell, S.; Mayorga, A.; Wu, L. Y.; Morre, D. M.; Arch. Biochem. Biophys. 1997, 342, 224.

27. Morre, D. J.; Davidson, M.; Geilen, C.; Lawrence, J.; Flesher, G.; Crowe, R.; Crane, F.L.; Biochem. J. 1993, 292, 647.
28. Hamachi, I.; Kobuke, Y.; J. Chem. Soc., Chem. Commun. 1989, $2,130$.

29. Jaegfeldt, H.; Torstensson, A.; Gorton, L.; Johansson, G.; Anal. Chem. 1981, 53, 1979.

30. Milagres, B. G.; Oliveira Neto, G.; Kubota, L. T.; Yamanaka, H.; Anal. Chim. Acta 1997, 347, 35.

31. Persson, B.; Gorton, L.; J. Electroanal. Chem. 1990, 292, 115.

32. Bocarsly, A.B.; Sinha, S.; J. Electroanal. Chem. 1982, 140, 167.

33. Gorton, L.; Csöregi, E.; Domínguez, E.; Emnéus, J.; JönssonPettersson, G.; Marko-Varga, G.; Persson, B.; Anal. Chim. Acta 1991, 250, 203.

34. Kitani, A.; So, Y-H.; Miller, L. L.; J. Am. Chem. Soc. 1981, 103, 7636.

35. Gorton, L.; J. Chem. Soc. Faraday Trans. I 1986, 82, 1245.

36. Gorton, L.; Electroanalysis 1995, 7, 23.

37. Huan, Z. W.; Persson, B.; Gorton, L.; Sahni, S.; Skotheim, T.; Bartlett, P.; Electroanalysis 1996, 8, 575.

38. Kubota, L. T.; Gouvea, F.; Andrade, A. N.; Milagres, B. G.; Oliveira Neto, G.; Electrochim. Acta 1996, 41, 1465.

39. Murray, R. W. In Electroanalytical Chemistry; Bard, A. J.; Dekker: New York, 1984, vol. 13, p. 191.

40. Kubota, L. T.; Gorton, L.; Electroanalysis 1999, 11, 719.

41. Molina, C. R.; Boujtita, M.; El Murr, N.; Anal. Chim. Acta 1999, 401, 155.

42. Brown, A. P.; Koval, C.; Anson, F. C.; J. Electroanal. Chem. 1976, 72, 379.

43. Malinauskas, A.; Ruzgas, T.; Gorton, L.; J. Electroanal. Chem. 2000, $484,55$.

44. Kubota, L. T.; Munteanu, F.; Roddick-Lanzilotta, A.; McQuillan, A. J.; Gorton, L.; Quim. Anal. 2000, 19, 15.

45. Springborg, J.; Olsen, C. E.; Sotofte, I.; Acta Chem. Scand. 1995, 49, 555.

46. Santos, A. S.; Gorton, L.; Kubota, L. T.; Electroanalysis in press.

47. Kubota, L. T.; Gorton, L.; Electroanalysis 1999, 11, 719.

48. Bard, A. J.; Faulker, L. R.; "Electrochemical Methods, Fundamentals and Applications”, Wiley, New York, 1980.

49. Pessoa, C.A.; Gushikem, Y.; Kubota, L.T.; Electroanalysis 1997, 9, 800.

50. Persson, B.; Gorton, L.; J. Electroanal. Chem. 1990, 292, 115.

51. Persson, B.; J. Electroanal. Chem. 1990, 287, 61.

52. Rover, L.; Fernandes, J. C. B.; Oliveira Neto, G.; Kubota, L. T.; Katekawa, E.; Serrano, S. H. P.; Anal. Biochem. 1998, 260, 50 .

Received: January 14, 2002

Published on the web: June 24, 2002

FAPESP helped in meeting the publication costs of this article. 